to others which will bring the engineer and scientific man into fruitful contact with the major problems of our time. If the project is attacked objectively by the scientific method, it should lead to results of social importance; and the core of the book really lies in Mr. Mills' plea for all scientific men of good will to join in an intelligent attack upon the social, economic and political problems of the day by an evolutionary application of the methods of science. Primarily that means a study of the problems of organisation, for the scientific method is to-day so little employed outside physical problems and, as Mr. Mills shows, is so diametrically opposed to the interests of particular classes, that its use in open attack may be impracticable. None the less, he believes its use is the last hope of our civilization, and his dignified plea for the engineer and scientific man to apply the objective method of science to the things directly affecting their lives and national surroundings without regard to inbred or subjective attitudes goes far to redeem his blemishes of style.

R. BRIGHTMAN

\section{WIRELESS DIRECTION FINDING}

\section{Wireless Direction Finding}

By R. Keen. Fourth edition. Pp. xii+1059. (London: Iliffe and Sons, Ltd., 1947.) 45s. net.

$7 \mathrm{HE}$ appearance of the fourth edition of this book will do much to dispel the impression, prevalent in some quarters, that the technique of radio direction finding has been rendered obsolete by the introduction and development of radar in recent years. As the author explains in his introductory chapter, there are several fields in which direction finding will still have commitments for many years to come. The relative simplicity of the equipment required to give guidance to ships and aircraft, and particularly to those in distress, makes it an invaluable aid to navigation; in another field, the network of direction finders provides the only means so far available of locating radio transmitting stations, and such information is frequently required under peacetime conditions as well as in time of war.

In spite of the fact that the present book excludes a discussion of radar technique as such, it is a consider. able enlargement on the previous edition, which was reprinted four times during the War. The only new chapter added describes the recently developed radio navigation systems such as 'Gee', 'Loran', 'Decca' and 'Consol', some of which use pulse modulation and some continuous-wave technique. The remaining chapters have been suitably expanded to include material descriptive of advances and developments; much of this material has only recently become available for publication.

Two of the most important additions are the sections on the calibration of direction-finding systems of various types, and on the classification of observed bearings. On both these subjects there has been much confused thinking in the past, and their detailed study has resulted in considerable improvement in the accuracy with which radio bearings can be obsirved and interpreted. The subject of radio wave propagation at both high and very high fre. quencies is treated somewhat more fully, since a detailed knowledge of this is fundamental to the successful exploitation of direction finding.

The book has been brought up to date also by the addition of details of new equipment developed both in Great Britain and in the United States, and including blind approach and landing systems for aircraft, improved forms of the Adcock and spacedloop aerial systems, and various types of cathode-ray tube presentation devices. The bibliography is, as in previous editions, an important feature of this book. With more than four hundred references, it forms a very useful guide to the literature of the subject, and it includes the titles of some papers still in course of publication.

As a comprehensive, practical manual on the various aspects of radio direction finding, the book can still be confidently recommended to students, engineers and other workers in this field.

\section{R. L. Smith-Rose}

\section{NEWTON TERCENTENARY CELEBRATIONS}

\section{Royal Society}

Newton Tercentenary Celebrations, 15-19 July 1946. Pp. $x v+92+6$ plates. (Cambridge : At the University Press, 1947.) 10s. 6d. net.

7 HE tercentenary of the birth of Sir Isaac Newton occurred in 1943. The Royal Society arranged at that time a commemorative meeting, and it was decided that more complete celebrations of an international character should be held after the War. These celebrations were held in July 1946, and invitations to send delegates were extended to the national academies of the world; in spite of the difficulties of travel, more than thirty countries were represented.

During the course of the commemorations, a number of addresses on various aspects of Newton's life and work were given, which were of considerable interest. These are all printed in the present volume, together with the list of delegates and the programme of the celebrations. It is well that they should be published in this way and so made available to a larger audience. The principal address, on "Newton", by Prof. E. N. da C. Andrade, gave a brilliant account of the life and achievements of Newton; in a very effective manner he called on the great men of science, from Newton's to the present time, to pay their tributes to Newton's genius. Among the other addresses of special interest were those on "Newton and the Atomic Theory" by Academician Vavilov; on "Newton: the Algebraist and Geometer", by Prof. H. W. Turnbull ; and on "Newton, the Man", by the late Lord Keynes, whicl was read by his brother, Mr. Geoffrey Keynes.

At the opening address to the delegates, the president of the Royal Society announced that the Chancellor of the Exchequer had agreed to ask Parliament to vote a sum of money sufficient to provide an Isaac Newton Observatory, to house a reflector of 100-in. diameter s a fitting national memorial to commemorate tercentenary of the birth of the greatest British man of science. The design of this telescope is now under consideration by a special board of management which has been constituted.

The volume is illustrated with three portraits of Newton, an old engraving showing Newton's rooms at Trinity College, Cambridge, a drawing of Woolsthorpe Manor by Mr. Hanslip Fletcher, and a reproduction of a letter from Newton to Halley. 